\title{
Feasibility Analysis of Financial Aspect in Determining Optimal Last Mile Warehouse Location Using P-Me- dian Method
}

\author{
Firlan Sbastian $^{1 *}$, Ari Yanuar Ridwan ${ }^{1}$, Nia Novitasari $^{1}$ \\ 1Industrial Engineering Faculty of Industrial Engineering Telkom University Telecommunication Street 1, Terusan \\ Buah batu-Bojongsoang, Bandung, Indonesia \\ ${ }^{*}$ Corresponding author. Email: firlansbastian@student.telkomuniversity.ac.id
}

\begin{abstract}
This research was conducted at a company engaged in the Iot Aquaculture sector with a product in the form of a shrimp smart feeder which was distributed to almost all islands in Indonesia. Based on an assessment made by the company in the product distribution aspect on the island of Sumatra, especially Bengkulu Province, it is considered still not optimal because there are still a number of cases where the last mile point is not able to meet the demand so that a decision is made to send it directly through the central distribution warehouse in the city of Bandung. This has an impact on the total distance and shipping costs to be large. Therefore, it is necessary to design long-term strategic steps in overcoming this, one of which is determining the location of the warehouse as a lastmile point to meet demand in the Bengkulu area with an optimal location by considering aspects of optimal location and financial feasibility. The method used in this study is a feasibility analysis using the calculation of the Net Present Value, Payback Period, and IRR, as well as determining the optimal location using the P-Median method with the Mixed Integer Linear Programming approach that used in parallel. The results showed that the location with the lowest demand-weighted distance and was declared feasible based on the feasibility analysis which was located in Kaur Regency. If this decision is made, the company can reduce the total cost of shipping the Bengkulu area that must be incurred by the company.
\end{abstract}

\section{Keywords: P-Median, Warehouse Location, Integer Linear Programming}

\section{INTRODUCTION}

Competition in the industrial sector over time continues to be tight so that it requires every company to be able to design strategies in order to superior in the market and be able to compete with competitors. In designing a strategy to carry out its business activities, it is expected to be able to provide added value for both parties, both internal to the company and consumers, as well as quality improvement. Quality improvement is not only done by making improvements to the product, but can also be done by improving distribution management and warehousing management, both of which are part of improving the company's logistics management [1]

The purpose of distribution management, especially in the supply chain, is cost optimization. There are components of distribution costs including Direct
Selling Expense, Advertising and Sales Promotion Expense, Transportation Expense, Werehousing and Storage Expense, General Distribution Costs Distribution Expenses) [2]. In general, there are several ways to reduce delivery time and delivery costs, one of the ways to reduce shipping costs is to determine the location of the facility [3].

In this case, the largest component of distribution costs at the IoT Aquaculture company is transportation costs where this cost accounts for $39.5 \%$ of the total distribution costs compared to other cost components where the transportation cost component of distribution costs still exceeds the company's target of $30 \%$. This is because there are still several parameters for evaluating the distribution aspect by operational management in several market areas, such as in this case the focus example on Sumatra Island, especially the market in Bengkulu Province which is considered not 
optimal. This problem arises because of the high demand from consumers who could not fulfill the existing last mile point warehouse because the location of the facility did not have sufficient capacity at that time so they decided to send it from the central warehouse in Bandung City and use it. Other lastmile points create

This study was conducted in parallel to solve this case by using the P-Median with MILP approach to determine the optimal location that minimizes the demandweighted distance and Feasibility Analysis with parameters NPV, PBP, and IRR. This settlement process is carried out in parallel with a goal based on the P-Median calculation to obtain optimal location results that minimize the demand-weighted distance, then all alternative locations are carried out with a financial aspect feasibility analysis to see the performance of the location when a rental decision is made whether it is profitable or not.

\section{METHODS}

\subsection{Location Model Taxonomy}

The location selection process has several location models which are divided into 4 namely analytical models, continuous models, networks models, and discrete models[5].

a. Analytics Mode

The analytical model is the easiest to use site selection model. This model assumes that demand is uniformly distributed in the service area and the location of the facility can be anywhere within the area. This model can be solved by calculus or other simple techniques [5].

b. Continuous Model

The location problem that is included in the continuous model is when the facility and the point of demand are a continuous one. The tools to solve this problem are analysis and geometry. The continuous model depends on the optimization process on linear and nonlinear programming [6].

c. Network Models

The assumption of the network model is that a network has a number of requests. The depiction of this model is the interconnectedness between the point of request and the point of location. In the network model, the facility location can be located anywhere on the network and requests will only appear on nodes. In various studies and literature the focus of this model is on finding polynomial time algorithms with structured network cases [5].

d. Discrete location model

A model that has limitations that demand arises at a point and that point can be used as an alternative location [5]. There are 3 types of discrete location considerable distance. This is also compounded by the reason that the initial site selection did not consider the site selection criteria, both proximity to potential markets, etc[4], so the company has not researched whether the existing location in the Bengkulu area is optimal apart from the capacity being too small. models:

i. Covering based models Set covering, max covering, and P-center

ii. Median based models P-Median and Fixed Charge

iii. Other Models

P-Dispersion

\subsection{P-Median}

The P-median problem is a model that determines a location with the aim of minimizing the average distance between the demand point and the facility location. There are several studies conducted by implementing the P-Median model, among others which compares the P-Median model with the P-Center model, max covering, and set covering [5]. The formulation model used in the comparison of these methods is a standard formulation model for each model, the conclusion is that the P-Median model is more commonly used with urgency when transportation costs aim to be minimized, besides that P-Median is used for distribution planning because the P-Median considers demand and distance and can place facilities in more congested areas than other models. In this study, the P-median model used as the initial basis is the P-Median model proposed by Daskin using the Mixed Integer Linear Programming approach [5]. This MILP approach has been widely used in solving optimization problems with the impact of reducing transportation costs as in the study by [7] to schedule cement transport vessels using MIRP with the MILP approach to minimize waiting time and transportation costs. The following is the P-Median equation of the MILP approach which is the reference for this research based on Daskin's research.

$$
\begin{aligned}
\text { Minimize : } & \sum j \in J \sum i \in I \text { hidijYij } \\
\text { Subject to }: & \sum j \in J Y i j=1 \forall \mathrm{i} \in \mathrm{I} \\
& \sum j \in J X j=p \\
& \mathrm{Yij}-\mathrm{Xj} \leq 0 \forall \mathrm{i} \in \mathrm{I} ; \forall \mathrm{j} \in \mathrm{J} \\
& \mathrm{Xj} \in\{0,1\} \forall \mathrm{i} \in \mathrm{J} \\
& Y \mathrm{ij} \in\{0,1\} \forall \mathrm{i} \in \mathrm{I} ; \forall \mathrm{j} \in \mathrm{J}
\end{aligned}
$$

Description:

I = union of demand points $\mathrm{i}$, 
I $\quad=\{1, \ldots \mathrm{n}\}$

$\mathrm{J}=$ concatenation of candidate point locations $\mathrm{j}$,

$\mathrm{J} \quad=\{1, \ldots \mathrm{m}\}$

dij = distance from alternative location $\mathrm{i}$ to cus-

tomer $\mathrm{j}$

hi $=$ customer demand $\mathrm{i}$

$\mathrm{p}=$ number of alternative facilities to be opened

$\mathrm{Xj}=\{1$, if the facility is opened on alternative $\mathrm{j}$ 0 , otherwise

Yij $=\{1$, if demand $\mathrm{i}$ can be satisfied by alterna-

tive $\mathrm{j} 0$, otherwise

\subsection{Feasibility Study}

A business feasibility study is a science that has the aim of finding out whether a business is feasible or not feasible (feasible or infeasible) to be carried out by placing measures both qualitatively and quantitatively [8]. According to [9] the purpose of the feasibility study is to carry out the process of evaluating alternative system solutions and to propose the most feasible business applications.

There are several aspects in the feasibility study which are the focus of attention, namely non-financial aspects (legal, market aspects, operational or technical aspects, organizational or management aspects, economic and social aspects, \& environmental impact aspects) and financial aspects [10]. The feasibility of a business can be seen through the financial aspect by using formula of Net Present Value, Payback period, and IRR.

\subsubsection{Net Present Value}

Net Present Value is the gap between the present value of cash in and cash out of cashflow over a period of time [11].So, the calculation of NPV relies on cash flow techniques. The formula for calculating NPV is as follows.

$$
N P V=\sum_{n=0}^{N}(R n-D n)\left(\frac{p}{f}, i \%, n\right)
$$

Description:

$\begin{array}{ll}\text { NPV } & : \text { Net Present Value } \\ \text { Rn } & : \text { Cash inflow } \\ \text { Dn } & : \text { Cash outflow } \\ (\mathrm{p} / \mathrm{f}, \mathrm{i} \%, \mathrm{n}) & \text { : Present and future factor with i\% in- }\end{array}$

terest rates

These are the criteria:

If NPV > 0, project proposals are worth to be considered.

If NPV $<0$, project proposals are rejected.

If $\mathrm{NPV}=0$, then the value of the company is 0 or same as capital, even though the project proposal was accepted/rejected.

\subsubsection{Payback Period}

Payback Period (PBP) is the time span for which the initial fee is refunded. Below is how to calculate PBP [12].

$$
\text { Payback Period }=\frac{\text { Investment }}{\text { cashflow }}
$$

Criteria:

if the payback period < return on investment target, that's means feasible. If payback period $>$ target return on investment, that's means not feasible.

\subsubsection{Internal Rate of Return (IRR)}

According to [12], that the Internal Rate of Return is implemented to find a suitable interest rate equates the present value of expected future cash flows, or cash receipts with make an initial investment. An investment plan is feasible if the IRR level exceeds the minimum level required by the investor. Vice versa, the investment plan is considered unfeasible. In other words, the investment requirements can be said to be feasible if: IRR > MAR. The formula used to get the Internal Rate of Return is as follows:

Notation:

$$
I R R=i 1+\frac{N V V r r}{T V P r r+T V P r t} \mathrm{x}(i 2-i 2)
$$

i2 : Negative NPV

Selection Criteria:

If the IRR $>$ of the required interest rate, that's means is feasible

If the IRR $<$ than the required interest rate, that's means is less or not feasible [12]

\subsection{Solution steps}

The initial step in this research is the criteria for market potential and other aspects that have been adjusted to the company's circumstances, which are then carried out several calculations to get three regencys or cities in the Bengkulu region which will be the focus of research using pairwise comparisons. The next stage, which is carried out in parallel, is to perform calculations to obtain an optimal alternative area using the PMedian Method. Then an investment study was conducted in three alternative locations using NPV, PBP and IRR and finally a decision-making process was carried out to determine the best and optimal location based on the criteria of each method. The following is the data needed in the solution. 


\section{RESULTS AND DISCUSSION}

First, there are three criteria in determining the location used to determine alternatives based on market potential and other aspects that have been determined by the company, namely the number of shrimp farmers, the number of shipping companies, and the number of rental buildings. The number of alternative locations that were chosen after being discussed with the company were three regencies or cities, which at the end of the study, 1 rental location was selected.

Table 1. Method and data used

\begin{tabular}{|c|c|}
\hline Method & Data \\
\hline $\begin{array}{l}\text { Pairwise } \\
\text { Comparion }\end{array}$ & $\begin{array}{l}\text { 1. Bengkulu province (city and re- } \\
\text { gency) data } \\
\text { 2. Number of shrimp farmers in } \\
\text { each city and regency } \\
\text { 3. Number of shipping expedi- } \\
\text { tions in each city and regency } \\
\text { 4. Number of building tenants in } \\
\text { each city and regency }\end{array}$ \\
\hline P-Median & $\begin{array}{l}\text { 1. Demand data Bengkulu } \\
\text { 2. Distance between rental facility } \\
\text { point and demand point }\end{array}$ \\
\hline $\begin{array}{l}\text { Feasibility } \\
\text { Analysis }\end{array}$ & $\begin{array}{l}\text { 1. Market aspect (demand and } \\
\text { sales plan) } \\
\text { 2. Management aspect (man- } \\
\text { power needed and salaries) } \\
\text { 3. Technical aspect (tangible as- } \\
\text { sets, depreciation, operational } \\
\text { cost, and transportation cost }\end{array}$ \\
\hline
\end{tabular}

The steps taken to determine alternative locations are the calculation of pairwise comparisons, the calculation of the rating value, and the calculation of the weighted value. The results of these calculations will obtain three alternative regions. The following is a calculation using pairwise comparisons from 10 regions, only 3 regions will be selected as below.

Based on the results obtained through the above calculations, three alternative regions were selected. The next process from each alternative city or regency is to look for building rental locations from several rental locations in each alternative area, adjusted to the minimum specifications of the building area that have been set by the company so that the building rental location is selected as follows.

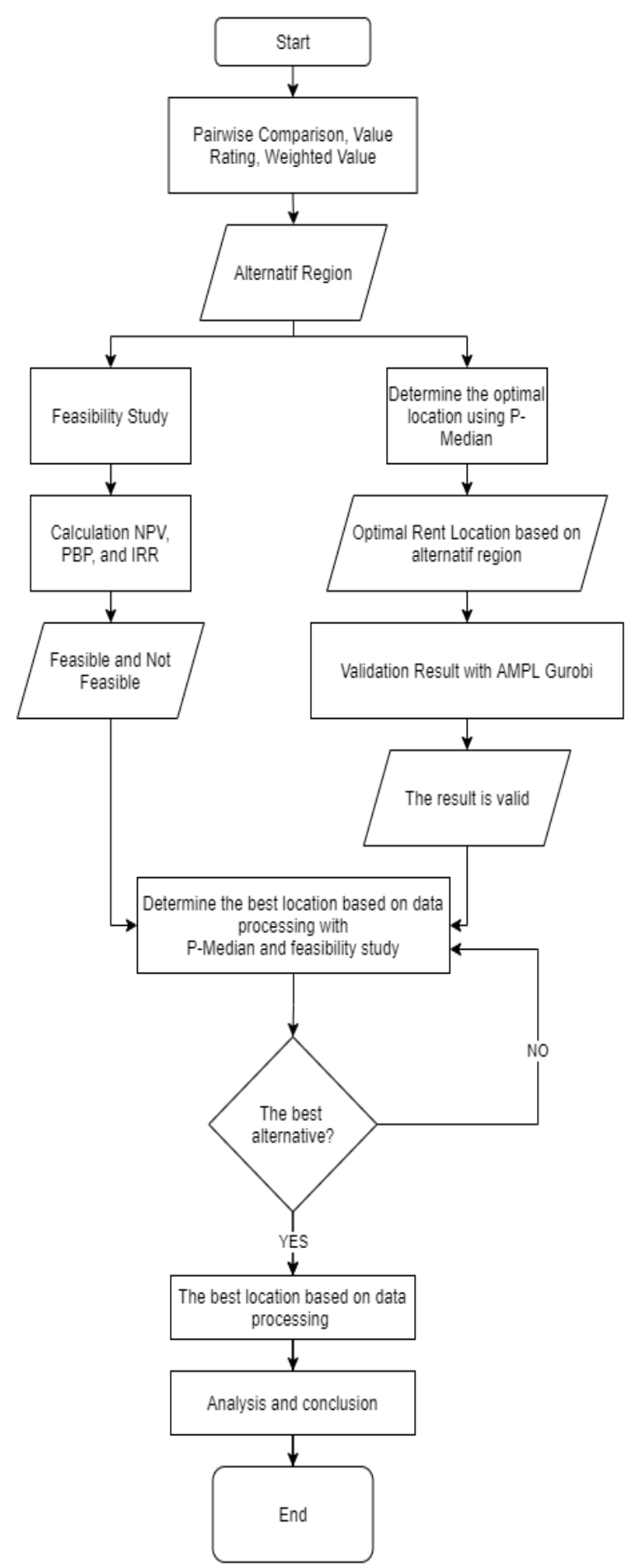

Figure. 1 Research Flowchart 
Table 2. Weighted Values for each Region

\begin{tabular}{|c|c|c|c|c|c|c|c|c|}
\hline No & Regency/City & SB & $\mathrm{a}$ & $\mathrm{EP}$ & $\mathrm{b}$ & $\mathrm{RM}$ & $\mathrm{c}$ & Weighted Value \\
\hline 1 & Bengkulu Selatan & 2.446 & 0.703 & 7.083 & 0.182 & 8.642 & 0.115 & 4.004 \\
\hline 2 & Bengkulu Tengah & 17.839 & 0.703 & 3.333 & 0.182 & 4.938 & 0.115 & 13.713 \\
\hline 3 & Bengkulu Utara & 18.960 & 0.703 & 6.250 & 0.182 & 4.938 & 0.115 & 15.033 \\
\hline 4 & Kaur & 25.841 & 0.703 & 10.417 & 0.182 & 12.346 & 0.115 & 21.479 \\
\hline 5 & Kepahiang & 7.135 & 0.703 & 5.000 & 0.182 & 9.877 & 0.115 & 7.061 \\
\hline 6 & Lebong & 0.000 & 0.703 & 2.917 & 0.182 & 6.173 & 0.115 & 1.241 \\
\hline 7 & Mukomuko & 10.448 & 0.703 & 10.000 & 0.182 & 9.877 & 0.115 & 10.301 \\
\hline 8 & Rejang Lebong & 0.000 & 0.703 & 9.167 & 0.182 & 12.346 & 0.115 & 3.089 \\
\hline 9 & Seluma & 10.245 & 0.703 & 1.667 & 0.182 & 6.173 & 0.115 & 8.213 \\
\hline 10 & Bengkulu & 7.085 & 0.703 & 44.167 & 0.182 & 24.691 & 0.115 & 15.866 \\
\hline
\end{tabular}

Yn $\quad=$ Weighted value of the regency or city

a $\quad=$ Weight of interest (priority vector) criteria for the number of cultivators

$\mathrm{b} \quad=$ Weight of importance criteria number of shiping companies

c $\quad=$ The weight of the importance of the criteria for the number of building leases

SB = Rating of the number of shrimp farmers in the city or regency

EP = Rating of the number of construction delivery expeditions in the city or regency

$\mathrm{RM} \quad=$ Rating of the number of rental buildings in the nth city or regency

\subsection{P-Median}

The first thing to do in the P-Median calculation is to need data as input, namely demand data and the distance from each alternative point of the facility location to each point of demand. The following is the demand data and the distance from each alternative location to the point of demand.

Table 3. The result of alternative rent location

\begin{tabular}{|l|l|c|}
\hline Regency/City & \multicolumn{1}{|c|}{ Address } & Rent Cost/year \\
\hline Kaur & $\begin{array}{l}\text { Jl Raya Pagar } \\
\text { Dewa No 87 }\end{array}$ & Rp24,000,000 \\
\hline Bengkulu & $\begin{array}{l}\text { Jl Manggis } \\
\text { (Pasar Pano- } \\
\text { rama) No 36A }\end{array}$ & Rp23,000,000 \\
\hline $\begin{array}{l}\text { North } \\
\text { Bengkulu }\end{array}$ & $\begin{array}{l}\text { Jl Arga Makmur } \\
\text { No 120 }\end{array}$ & Rp43,250,000 \\
\hline
\end{tabular}

Table 4. Demand data

\begin{tabular}{|c|l|c|}
\hline No & \multicolumn{1}{|c|}{ Customer Name } & Qty \\
\hline 1 & $\begin{array}{l}\text { PT. DUA PUTRA PERKASA } \\
\text { PRATAMA }\end{array}$ & 20 \\
\hline 2 & PT. GLOBAL FEED & 14 \\
\hline 3 & EKO TEGUH HARIYANTO & 18 \\
\hline 4 & MUNAWIR & 12 \\
\hline 5 & PT EHT & 12 \\
\hline 6 & BAMBANG KS & 22 \\
\hline 7 & PT EHT B & 22 \\
\hline 8 & BUDI S & 15 \\
\hline 9 & JOKO SUGIANTORO & 25 \\
\hline 10 & PT. GLOBAL FEED B & 8 \\
\hline 11 & PT SENTOSA & 6 \\
\hline 12 & NYOMAN & 14 \\
\hline 13 & PT SENTRA & 5 \\
\hline 14 & PT LAUT BIRU & 26 \\
\hline 15 & PT INTERACO LAUT BIRU & 6 \\
\hline 16 & SOFYAN & 11 \\
\hline 17 & PT EVERGREEN & \\
\hline & & 11 \\
\hline
\end{tabular}


Table 5. Distance data from alternative rental locations to the point of demand

\begin{tabular}{|c|l|c|c|c|}
\hline No & \multicolumn{1}{|c|}{ Customer Name } & Kaur & Bengkulu & North Bengkulu \\
\hline 1 & PT. DUA PUTRA PERKASA PRATAMA & 168 & 10 & 72 \\
\hline 2 & PT. GLOBAL FEED & 86 & 110 & 264 \\
\hline 3 & EKO TEGUH HARIYANTO & 38 & 207 & 205 \\
\hline 4 & MUNAWIR & 43 & 147 & 200 \\
\hline 5 & PT EHT & 50 & 148 & 263 \\
\hline 6 & BAMBANG KS & 33 & 202 & 200.7 \\
\hline 7 & PT EHT B & 50.5 & 148.3 & 28 \\
\hline 8 & BUDI S & 211 & 40 & 264 \\
\hline 9 & JOKO SUGIANTORO & 30 & 203 & 28 \\
\hline 10 & PT. GLOBAL FEED B & 86.3 & 111 & 29 \\
\hline 11 & PT SENTOSA & 205 & 40 & 126 \\
\hline 12 & NYOMAN & 206 & 42 & 34.1 \\
\hline 13 & PT SENTRA & 122 & 73 & 193 \\
\hline 14 & PT LAUT BIRU & 202 & 30.5 & 35 \\
\hline 15 & PT INTERACO LAUT BIRU & 53.5 & 141 & 260 \\
\hline 16 & SOFYAN & 203 & 33 & 199 \\
\hline 17 & PT EVERGREEN & 29 & & \\
\hline
\end{tabular}

And then this the distance data between demand and alternative rental location that will be process in $P$-Median. Based on the results of the weighted values shown in Table 6 .

Table 6. The Result of P-Median Calculation

\begin{tabular}{|c|c|c|c|}
\hline No & Location & $\begin{array}{l}\text { Demand- } \\
\text { Weighted } \\
\text { Distance }\end{array}$ & Rank \\
\hline 1 & $\begin{array}{l}\text { Kaur Regency } \\
\text { (Jl. Raya Pagar Dewa } \\
\text { No 87) }\end{array}$ & 25655 & 1 \\
\hline 2 & $\begin{array}{l}\text { Bengkulu City } \\
\text { (Jl Manggis (Pasar } \\
\text { Panorama) No 36A) }\end{array}$ & 28660 & 2 \\
\hline 3 & $\begin{array}{l}\text { Bengkulu Utara Re- } \\
\text { gency } \\
\text { (Jl Arga Makmur No } \\
\text { 120) }\end{array}$ & 38452 & 3 \\
\hline
\end{tabular}

Three regencies or cities were chosen as alternatives, namely Kaur Regency, Bengkulu City, and North Bengkulu Regency. After determining the three selected alternative locations, then determining the optimal area for each selected regency and city using the P-Median Method with the MILP approach and the criterion being considered is the smallest demand-weighted distance. The results are shown in the table below.
The next process is a validation process to check whether the calculation results are the same using the Gurobi AMPL program as shown in the following figure.

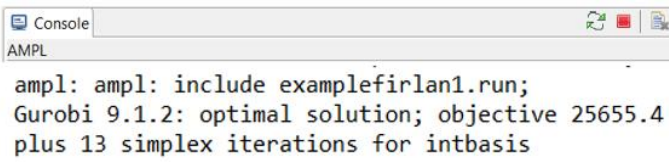

Figure 2 Validation of P-Median Calculation between Excel Solver and AMPL

Based on the validation results showing the similarity of the results, the results can be said to be valid with the first optimal location chosen, namely warehouse rental in Kaur Regency.

\subsection{Feasibility Study}

The next parallel step is to carry out an investment feasibility analysis of each alternative rental location previously determined. This investment feasibility study will be processed using the calculation of Net Present Value (NPV), Payback period, and IRR with the criteria considered are NPV $>0$, Payback Period $<5$ years, and IRR > MARR.

In the calculation of the feasibility analysis, it is necessary to need data in the investment that will be carried 
Table 7. Sales Plan

\begin{tabular}{|l|c|c|c|c|c|c|c|}
\hline \multicolumn{2}{|c|}{ Period } & 0 & 1 & 2 & 3 & 4 & 5 \\
\hline Regency/City & $\begin{array}{c}\text { Demand } \\
2020\end{array}$ & 2021 & 2022 & 2023 & 2024 & 2025 & 2026 \\
\hline Kaur & 76 & 84 & 93 & 103 & 114 & 126 & 139 \\
\hline Bengkulu & 20 & 22 & 25 & 28 & 31 & 35 & 39 \\
\hline $\begin{array}{l}\text { North } \\
\text { Bengkulu }\end{array}$ & 72 & 80 & 88 & 97 & 107 & 118 & 130 \\
\hline Seluma & 27 & 30 & 33 & 37 & 41 & 46 & 51 \\
\hline $\begin{array}{l}\text { Central } \\
\text { Bengkulu }\end{array}$ & 52 & 58 & 64 & 71 & 79 & 87 & 96 \\
\hline TOTAL & 247 & 274 & 303 & 336 & 372 & 412 & 455 \\
\hline
\end{tabular}

out based on several aspects such as market, management, and technical aspects. The following is the market aspect data that is projected for the next 5 years with inflation of $10 \%$ (based on the growth of target customer of this product).

The following is a profit and loss report for alternative rental locations in Kaur Regency which provides information related to income data originating from revenue and expenditure data on costs.
Then the last step is to calculate the feasibility analysis using the NPV, PBP, and IRR parameters from each alternative rental location. The following is an analysis of rental location in Kaur regency.

Table 8. Profit and loss Kaur Regency

\begin{tabular}{|c|c|c|c|}
\hline \multicolumn{4}{|c|}{ Profit and Loss (Kaur) } \\
\hline Year & 2022 & 2023 & 2024 \\
\hline Revenue & $\operatorname{Rp} 256,214,281.46$ & Rp $\quad 292,102,545.65$ & $\mathrm{Rp} \quad 332,486,765.81$ \\
\hline \multicolumn{4}{|l|}{ Cost } \\
\hline Building Depreciation Cost & $\mathrm{Rp}$ & $\mathrm{Rp}$ & $\mathrm{Rp}$ \\
\hline Facility Depreciation Cost & $\operatorname{Rp~4,286,000.00}$ & Rp $4,286,000.00$ & Rp 4,286,000.00 \\
\hline Labor Cost & Rp 197,531,317.76 & Rp 211,359,000.00 & Rp226,155,000.00 \\
\hline Rental Cost & $\operatorname{Rp} 24,000,000.00$ & Rp 24,674,400.00 & Rp 25,367,750.64 \\
\hline Electricity Cost & Rp $7,200,000.00$ & Rp $7,402,320.00$ & Rp 7,610,325.19 \\
\hline Internet Cost & Rp $4,800,000.00$ & Rp $\quad 4,934,880.00$ & Rp 5,073,550.13 \\
\hline Petty Cash & Rp $12,000,000.00$ & Rp $12,337,200.00$ & Rp 12,683,875.32 \\
\hline Transportation Cost & Rp $14,188,210.83$ & $\operatorname{Rp} \quad 15,607,031.91$ & $\operatorname{Rp} 17,167,735.10$ \\
\hline Total Cost & Rp264,005,528.59 & $\operatorname{Rp} \quad 280,600,831.91$ & Rp 298,344,236.38 \\
\hline $\begin{array}{l}\text { EBIT (Earning Before Inter- } \\
\text { est and Tax) }\end{array}$ & $\operatorname{Rp}(7,791,247.12)$ & $1,501,713.74$ & Rp $34,142,529.43$ \\
\hline Interest Rate & $\mathrm{Rp}$ & $\mathrm{Rp}$ & $\mathrm{Rp}$ \\
\hline EBT (Earning Before Tax) & $\operatorname{Rp}(7,791,247.12)$ & Rp11,501,713.74 & Rp 34,142,529.43 \\
\hline Tax & $\operatorname{Rp}(78,000.00)$ & Rp $115,000.00$ & Rp $341,000.00$ \\
\hline $\begin{array}{l}\text { EAIT (Earning After Interes- } \\
\text { tand Tax) }\end{array}$ & $\operatorname{Rp}(7,713,247.12)$ & Rp $11,386,713.74$ & Rp33,801,529.43 \\
\hline Depreciation & $\operatorname{Rp~4,286,000.00}$ & Rp 4,286,000.00 & $\operatorname{Rp~4,286,000.00}$ \\
\hline EAT & $\operatorname{Rp}(3,427,247.12)$ & Rp 15,672,713.74 & Rp 38,087,529.43 \\
\hline
\end{tabular}


Table 8 (continued..)

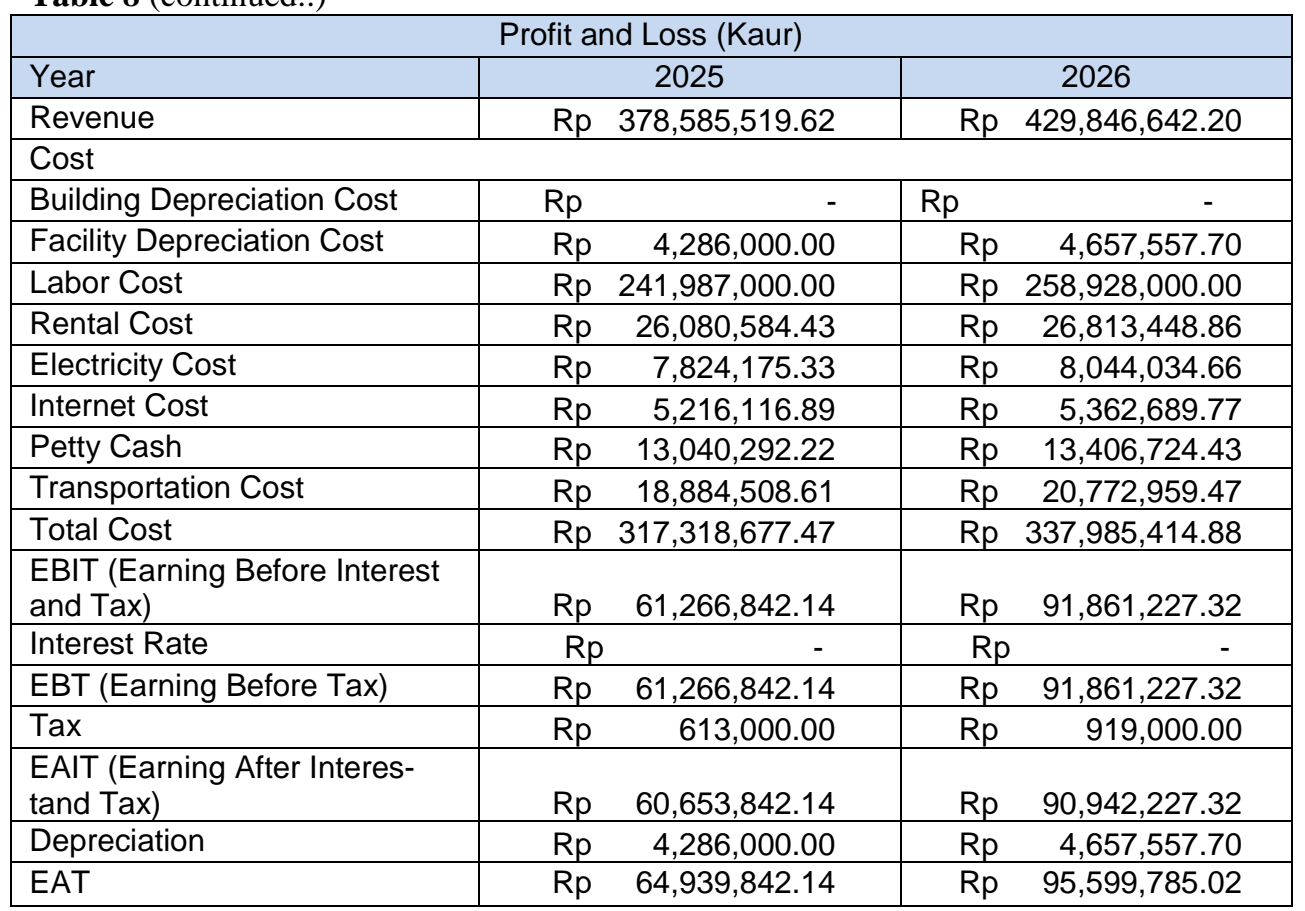

Table 9. Profit and loss Bengkulu City

\begin{tabular}{|c|c|c|c|}
\hline \multicolumn{4}{|c|}{ Profit and Loss (Bengkulu) } \\
\hline Year & 2022 & 2023 & 2024 \\
\hline Revenue & Rp256,214,281.46 & Rp292,102,545.65 & Rp332,486,765.81 \\
\hline \multicolumn{4}{|l|}{ Cost } \\
\hline $\begin{array}{l}\text { Building Deprecia- } \\
\text { tion Cost }\end{array}$ & $\mathrm{Rp}$ & $\mathrm{Rp}$ & $\mathrm{Rp}$ \\
\hline $\begin{array}{l}\text { Facility Depreciation } \\
\text { Cost }\end{array}$ & Rp3,904,750.00 & Rp $3,904,750.00$ & Rp3,904,750.00 \\
\hline Labor Cost & Rp197,531,317.76 & Rp211,359,000.00 & Rp $226,155,000$ \\
\hline Rental Cost & $\operatorname{Rp~23,000,000.00}$ & $\operatorname{Rp} 23,646,300.00$ & Rp $\quad 24,310,761.03$ \\
\hline Electricity Cost & $\operatorname{Rp} 7,200,000.00$ & Rp 7,402,320.00 & $7,610,325.19$ \\
\hline Internet Cost & Rp $4,800,000.00$ & $\operatorname{Rp} 4,934,880.00$ & $5,073,550.13$ \\
\hline Petty Cash & $\operatorname{Rp} 12,000,000.00$ & Rp12,337,200.00 & $12,683,875.32$ \\
\hline Transportation Cost & Rp 15,163,349.62 & $\operatorname{Rp~16,679,684.58}$ & Rp $\quad 18,347,653.04$ \\
\hline Total Cost & $\operatorname{Rp} 263,599,417.38$ & Rp280,264,134.58 & Rp $298,085,914.71$ \\
\hline $\begin{array}{l}\text { EBIT (Earning Be- } \\
\text { fore Interest and } \\
\text { Tax) }\end{array}$ & $\operatorname{Rp}(7,385,135.92)$ & Rp11,838,411.07 & Rp $\quad 34,400,851.10$ \\
\hline Interest Rate & $\mathrm{Rp}$ & $\mathrm{Rp}$ & $\mathrm{Rp}$ \\
\hline $\begin{array}{l}\text { EBT (Earning Before } \\
\text { Tax) }\end{array}$ & $\mathrm{Rp}(7,385,135.92)$ & Rp11,838,411.07 & $34,400,851.10$ \\
\hline $\operatorname{Tax}$ & $\operatorname{Rp}(74,000.00)$ & $\mathrm{Rp} \quad 118,000.00$ & $344,000.00$ \\
\hline $\begin{array}{l}\text { EAIT (Earning After } \\
\text { Interestand Tax) }\end{array}$ & $\mathrm{Rp}(7,311,135.92)$ & Rp 11,720,411.07 & $34,056,851.10$ \\
\hline Depreciation & $\operatorname{Rp} 3,904,750.00$ & $\operatorname{Rp~3,904,750.00}$ & $3,904,750.00$ \\
\hline EAT & $\mathrm{Rp}(3,406,385.92)$ & Rp15,625,161.07 & $37,961,601.10$ \\
\hline
\end{tabular}


Table 9 (continued)

\begin{tabular}{|c|c|c|}
\hline \multicolumn{3}{|c|}{ Profit and Loss (Bengkulu) } \\
\hline Year & 2025 & 2026 \\
\hline Revenue & $\mathrm{Rp} \quad 378,585,519.62$ & $\mathrm{Rp} \quad 429,846,642.20$ \\
\hline \multicolumn{3}{|l|}{ Cost } \\
\hline Building Depreciation Cost & $\mathrm{Rp}$ & $\mathrm{Rp}$ \\
\hline Facility Depreciation Cost & $3,904,750.00$ & $4,243,256.75$ \\
\hline Labor Cost & Rp $241,987,000.00$ & Rp $258,929,000.00$ \\
\hline Rental Cost & $24,993,893.41$ & $25,696,221.82$ \\
\hline Electricity Cost & $7,824,175.33$ & $8,044,034.66$ \\
\hline Internet Cost & $5,216,116.89$ & $5,362,689.77$ \\
\hline Petty Cash & $13,040,292.22$ & $13,406,724.43$ \\
\hline Transportation Cost & $20,182,418.35$ & $22,200,660.18$ \\
\hline Total Cost & $\mathrm{Rp} \quad 317,148,646.19$ & Rp $337,882,587.61$ \\
\hline EBIT (Earning Before Interest and Tax) & $61,436,873.43$ & $\mathrm{Rp} \quad 91,964,054.60$ \\
\hline Interest Rate & $\mathrm{Rp}$ & $\mathrm{Rp}$ \\
\hline EBT (Earning Before Tax) & $61,436,873.43$ & Rp $91,964,054.60$ \\
\hline Tax & $614,000.00$ & $920,000.00$ \\
\hline EAIT (Earning After Interest and Tax) & $60,822,873.43$ & $91,044,054.60$ \\
\hline Depreciation & $3,904,750.00$ & $4,243,256.75$ \\
\hline EAT & $64,727,623.43$ & Rp 95,287,311.35 \\
\hline
\end{tabular}

Table 10. Profit and loss North Bengkulu Regency

\begin{tabular}{|c|c|c|c|}
\hline \multicolumn{4}{|c|}{ Profit and Loss (North Bengkulu) } \\
\hline Year & 2022 & 2023 & 2024 \\
\hline Revenue & $\operatorname{Rp} 256,214,281.46$ & $\operatorname{Rp} 292,102,545.65$ & Rp332,486,765.81 \\
\hline \multicolumn{4}{|l|}{ Cost } \\
\hline Building Depreciation Cost & $\mathrm{Rp}$ & $\mathrm{Rp}$ & $\mathrm{Rp}$ \\
\hline Facility Depreciation Cost & $\mathrm{Rp} 3,523,500.00$ & Rp3,523,500.00 & Rp3,523,500.00 \\
\hline Labor Cost & Rp197,531,317.76 & $\mathrm{Rp} 211,359,000.00$ & Rp226,155,000.00 \\
\hline Rental Cost & $\operatorname{Rp~43,750,000.00}$ & $\operatorname{Rp} 44,979,375.00$ & $\operatorname{Rp~46,243,295.44~}$ \\
\hline Electricity Cost & $\operatorname{Rp} 7,200,000.00$ & $\operatorname{Rp} 7,402,320.00$ & Rp7,610,325.19 \\
\hline Internet Cost & $\mathrm{Rp} \quad 4,800,000.00$ & Rp 4,934,880.00 & $\operatorname{Rp} 5,073,550.13$ \\
\hline Petty Cash & $\operatorname{Rp~} 12,000,000.00$ & Rp12,337,200.00 & Rp12,683,875.32 \\
\hline Transportation Cost & Rp20,376,353.23 & $\operatorname{Rp} 22,413,988.55$ & Rp24,655,387.41 \\
\hline Total Cost & Rp289,181,170.99 & Rp306,950,263.55 & Rp 325,944,933.48 \\
\hline $\begin{array}{l}\text { EBIT (Earning Before Interest and } \\
\text { Tax) }\end{array}$ & $\mathrm{Rp}(32,966,889.52)$ & $\operatorname{Rp}(14,847,717.90)$ & Rp 6,541,832.33 \\
\hline Interest Rate & $\mathrm{Rp}$ & $\mathrm{Rp}$ & $\mathrm{Rp}$ \\
\hline EBT (Earning Before Tax) & $\operatorname{Rp}(32,966,889.52)$ & $\operatorname{Rp}(14,847,717.90)$ & $\operatorname{Rp} 6,541,832.33$ \\
\hline Tax & $R p(330,000.00)$ & $\operatorname{Rp}(148,000.00)$ & $\mathrm{Rp} \quad 65,000.00$ \\
\hline $\begin{array}{l}\text { EAIT (Earning After Interest and } \\
\text { Tax) }\end{array}$ & $\mathrm{Rp}(32,636,889.52)$ & $\operatorname{Rp}(14,699,717.90)$ & Rp6,476,832.33 \\
\hline Depreciation & $\mathrm{Rp} 3,523,500.00$ & $\operatorname{Rp} 3,523,500.00$ & Rp3,523,500.00 \\
\hline EAT & $\mathrm{Rp}(29,113,389.52)$ & $\mathrm{Rp}(11,176,217.90)$ & Rp10,000,332.33 \\
\hline
\end{tabular}


Table 10. (continued)

\begin{tabular}{|c|c|c|}
\hline \multicolumn{3}{|c|}{ Profit and Loss (North Bengkulu) } \\
\hline Year & 2025 & 2026 \\
\hline Revenue & Rp $378,585,519.62$ & Rp $429,846,642.2 C$ \\
\hline \multicolumn{3}{|l|}{ Cost } \\
\hline Building Depreciation Cost & $\mathrm{Rp}$ & $\mathrm{Rp}$ \\
\hline Facility Depreciation Cost & $3,523,500.00$ & $3,828,955.80$ \\
\hline Labor Cost & $\mathrm{Rp} \quad 241,987,000.00$ & $\operatorname{Rp} 258,929,000.00$ \\
\hline Rental Cost & $\mathrm{Rp} \quad 47,542,732.04$ & Rp $\quad 48,878,682.81$ \\
\hline Electricity Cost & $7,824,175.33$ & $8,044,034.66$ \\
\hline Internet Cost & $5,216,116.89$ & $5,362,689.77$ \\
\hline Petty Cash & $13,040,292.22$ & $13,406,724.43$ \\
\hline Transportation Cost & $\mathrm{Rp} \quad 27,120,926.15$ & $29,833,018.76$ \\
\hline Total Cost & $\mathrm{Rp} \quad 346,254,742.62$ & $\operatorname{Rp} 368,283,106.23$ \\
\hline EBIT (Earning Before Interest and Tax) & $\begin{array}{ll}\mathrm{Rp} & 32,330,777.00\end{array}$ & Rp $\quad 61,563,535.98$ \\
\hline Interest Rate & $\mathrm{Rp}$ & $\mathrm{Rp}$ \\
\hline EBT (Earning Before Tax) & Rp $32,330,777.00$ & $\begin{array}{ll}\mathrm{Rp} & 61,563,535.98 \\
\end{array}$ \\
\hline Tax & $323,000.00$ & $616,000.00$ \\
\hline EAIT (Earning After Interestand Tax) & $\mathrm{Rp} \quad 32,007,777.00$ & $60,947,535.98$ \\
\hline Depreciation & $3,523,500.00$ & $3,828,955.80$ \\
\hline EAT & $\mathrm{Rp} \quad 35,531,277.00$ & Rp $\quad 64,776,491.7 \varepsilon$ \\
\hline
\end{tabular}

Table 11. Feasibility Analysis Kaur Regency

\begin{tabular}{|l|c|c|c|}
\hline \multicolumn{1}{|c|}{ Year } & 2021 & 2022 & 2023 \\
\hline Period & 0 & 1 & 2 \\
\hline Initial Cash Flow (Cash Out) & $\mathrm{Rp} 82,073,882$ & & \\
\hline Operational Cash Flow (Cash In) & $\mathrm{Rp}-$ & $\mathrm{Rp}(3,427,247)$ & $\mathrm{Rp} 15,672,714$ \\
\hline Salvage Value & & & \\
\hline Working Capital & & & \\
\hline Net Cash & $\mathrm{Rp}(82,073,882)$ & $\mathrm{Rp}(3,427,247)$ & $\mathrm{Rp} 15,672,714$ \\
\hline P/f Factor & 1 & 0.9095 & 0.8272 \\
\hline NPV & $\mathrm{Rp}(82,073,882)$ & $\mathrm{Rp}(3,117,096)$ & $\mathrm{Rp} 12,964,439$ \\
\hline NPV Cumulative & $\mathrm{Rp}(82,073,882)$ & $\mathrm{Rp}(85,190,978)$ & $\mathrm{Rp}(72,226,539)$ \\
\hline
\end{tabular}

Table 11 (continued)

\begin{tabular}{|c|c|c|c|}
\hline Year & 2024 & 2025 & 2026 \\
\hline Period & 3 & 4 & 5 \\
\hline \multicolumn{4}{|l|}{ Initial Cash Flow (Cash Out) } \\
\hline Operational Cash Flow (Cash In) & Rp38,087,529 & Rp64,939,842 & $\operatorname{Rp} 95,599,785$ \\
\hline Salvage Value & & & $\operatorname{Rp} 4,657,558$ \\
\hline Working Capital & & & Rp64,929,882 \\
\hline Net Cash & Rp38,087,529 & Rp 64,939,842 & Rp165,187,225 \\
\hline P/f Factor & 0.7523 & 0.6843 & 0.6223 \\
\hline NPV & Rp28,654,782 & Rp 44,435,523 & Rp102,801,698 \\
\hline NPV Kumulatif & $\mathrm{Rp}(43,571,758)$ & Rp 863,765 & Rp103,665,463 \\
\hline
\end{tabular}


Table 12. Value of feasibility Analysis Kaur

\begin{tabular}{|c|c|c|}
\hline Parameter & & Value \\
\hline Interest Rate & & $9.95 \%$ \\
\hline NPV & $\mathrm{Rp}$ & $103,665,463.4$ \\
\hline PBP & & 3.019 \\
\hline IRR & & $33.8 \%$ \\
\hline
\end{tabular}

Table 13. Feasibility Analysis Bengkulu City

\begin{tabular}{|l|l|l|l|}
\hline Year & 2021 & 2022 & 2023 \\
\hline Period & 0 & 1 & 2 \\
\hline Initial cash flow (cash out) & Rp82,073,882 & & \\
\hline $\begin{array}{l}\text { Operation cash flow (cash } \\
\text { in) }\end{array}$ & & $\mathrm{Rp3,406,386}$ & $\mathrm{Rp} 15,625,161$ \\
\hline Salvage valve & & & \\
\hline Working capital & & & \\
\hline Net cash & $\mathrm{Rp82,073,882}$ & $\mathrm{Rp3,406,386}$ & $\mathrm{Rp} 15,525,161$ \\
\hline P/f factor & 1 & 0,9095 & 0,8272 \\
\hline NPV & $\mathrm{Rp82,073,882}$ & $\mathrm{Rp} 85,172,005$ & $\mathrm{Rp} 72,246,901$ \\
\hline
\end{tabular}

Table 13. (continued)

\begin{tabular}{|l|l|l|l|}
\hline Year & 2024 & 2025 & 2026 \\
\hline Period & 3 & 4 & 5 \\
\hline Initial cash flow (cash out) & & & \\
\hline $\begin{array}{l}\text { Operation cash flow (cash } \\
\text { in) }\end{array}$ & Rp37,961,601 & Rp64,727,623 & Ro95,287,311 \\
\hline Salvage valve & & & $R p 4,243,257$ \\
\hline Working capital & & & $R p 64,929,882$ \\
\hline Net cash & Rp37,961,601 & $R p 64,727,623$ & Ro164,469,459 \\
\hline P/f factor & 0,7523 & 0,6843 & 0,6223 \\
\hline NPV & $R p 28,560,041$ & $R p 44,290,311$ & $R p 102,349,401$ \\
\hline NPV cumulative & $R p 43,686,861$ & $R p 603,450$ & $R p 102,952,851$ \\
\hline
\end{tabular}

So, this is the summary of parameter in feasibility analysis using NPV, PBP, and IRR of Kaur Regency.

\footnotetext{
$\mathrm{NPV}=\operatorname{Rp}(82,073,882)+\mathrm{Rp}(3,117,096)+$ $\mathrm{Rp} 12,964,439+\mathrm{Rp} 28,654,782+\mathrm{Rp} 44,435,523$ + Rp $102,801,698$ $=\mathrm{Rp} 103,665,463$

$\begin{aligned} \text { PBP } & =3+\left(\frac{R p 863,765}{R p 863,765-(-R p 43,571,758)}\right) \\ & =3.019\end{aligned}$
}

$\begin{aligned} \mathrm{IRR} & =30 \%+\frac{R p 9,126,688}{-R p 15,117,639} \times(40 \%-30 \%) \\ & =33.8 \%\end{aligned}$

Next is feasibility analysis of rental locations in Bengkulu City as in the Table 17 and Table 18.

So, this is the summary of parameter in feasibility analysis using NPV, PBP, and IRR of Bengkulu City. 


$$
\begin{aligned}
\mathrm{NPV} & =\operatorname{Rp}(82,073,882)+\operatorname{Rp}(3,098,123)+ \\
& \mathrm{Rp} 12,925,104+\mathrm{Rp} 28,560,041+\mathrm{Rp} 44,290,311 \\
& +\mathrm{Rp} 102,349,401 \\
= & \mathrm{Rp} 102,952,851
\end{aligned}
$$

$\mathrm{PBP}=3+\left(\frac{R p 603,450}{R p 603,450-(-R p 43,686,861)}\right)$

$$
=3.014
$$$$
\begin{aligned}
\text { IRR } & =30 \%+\frac{R p 8,787,235}{-R p 15,362,715} \times(40 \%-30 \%) \\
& =33.6 \%
\end{aligned}
$$

Table 14. Value of feasibility Analysis

\begin{tabular}{|c|c|c|c|}
\hline Year & 2021 & 2022 & 2023 \\
\hline Period & 0 & 1 & 2 \\
\hline $\begin{array}{l}\text { Initial cash } \\
\text { flow (cash out) }\end{array}$ & $\begin{array}{l}\text { Rp82,07 } \\
3,882\end{array}$ & & \\
\hline $\begin{array}{l}\text { Operation } \\
\text { cash flow } \\
\text { (cash in) }\end{array}$ & & $\begin{array}{l}\text { Rp29,11 } \\
3,390\end{array}$ & $\begin{array}{l}\text { Rp11,176, } \\
218\end{array}$ \\
\hline \multicolumn{4}{|l|}{ Salvage valve } \\
\hline \multicolumn{4}{|l|}{$\begin{array}{l}\text { Working capi- } \\
\text { tal }\end{array}$} \\
\hline Net cash & $\begin{array}{l}\text { Rp82,07 } \\
3,882 \\
\end{array}$ & $\begin{array}{l}\text { Rp29,11 } \\
3,390 \\
\end{array}$ & $\begin{array}{l}\text { Rp11,176, } \\
218\end{array}$ \\
\hline $\mathrm{P} / \mathrm{f}$ factor & 1 & 0,9095 & 0,8272 \\
\hline NPV & $\begin{array}{l}\text { Rp82,07 } \\
3,882\end{array}$ & $\begin{array}{l}\text { Rp26,47 } \\
8,754\end{array}$ & $\begin{array}{l}\text { Rp9,244,9 } \\
46\end{array}$ \\
\hline $\begin{array}{l}\text { NPV cumula- } \\
\text { tive }\end{array}$ & $\begin{array}{l}\text { Rp82,07 } \\
3,882\end{array}$ & $\begin{array}{l}\text { Rp108,5 } \\
52,636\end{array}$ & $\begin{array}{l}\text { Rp117,79 } \\
7,582\end{array}$ \\
\hline
\end{tabular}
Bengkulu

\begin{tabular}{|l|rr|}
\hline \multicolumn{1}{|c|}{ Parameter } & \multicolumn{2}{|c|}{ Value } \\
\hline Interest Rate & \multicolumn{2}{|c|}{$9.95 \%$} \\
\hline NPV & Rp & $102,952,851.3$ \\
\hline PBP & & 3.014 \\
\hline IRR & & $33.6 \%$ \\
\hline
\end{tabular}

Table 15. Feasibility Analysis North Bengkulu Regency
Table 16. Feasibility Analysis North Bengkulu Regency (continued)

\begin{tabular}{|l|l|l|l|}
\hline Year & 2024 & 2025 & 2026 \\
\hline Period & 3 & 4 & 5 \\
\hline $\begin{array}{l}\text { Initial cash } \\
\text { flow (cash out) }\end{array}$ & & & \\
\hline $\begin{array}{l}\text { Operation } \\
\text { cash flow } \\
\text { (cash in) }\end{array}$ & $\begin{array}{l}\mathrm{Rp} 10,00 \\
0,332\end{array}$ & $\begin{array}{l}\mathrm{Rp} 35,53 \\
1,277\end{array}$ & $\begin{array}{l}\text { Rp64,776, } \\
492\end{array}$ \\
\hline Salvage valve & & & $\mathrm{Rp3,828,9}$ \\
& & & 56 \\
\hline Working capi- \\
tal & & & $\mathrm{Rp} 64,929$, \\
\hline Net cash & $\mathrm{Rp} 10,00$ & $35,531,2$ & $\mathrm{Rp} 133,53$ \\
& 0,332 & 77 & 5,330 \\
\hline P/f factor & 0,7523 & 0,6843 & 0,6223 \\
\hline NPV & $\mathrm{Rp7,523,}$ & $\mathrm{Rp24,31}$ & $\mathrm{Rp} 83,103$, \\
& 653 & 2,515 & 634 \\
\hline $\begin{array}{l}\text { NPV cumula- } \\
\text { tive }\end{array}$ & $\mathrm{Rp} 110,2$ & $\mathrm{Rp} 85,96$ & $\mathrm{Rp} 2,857,7$ \\
73,929 & 1,415 & 81 \\
\hline
\end{tabular}

Table 17. Value of feasibility Analysis North Bengkulu Regency

\begin{tabular}{|l|r|}
\hline Parameter & Value \\
\hline Interest Rate & $9.95 \%$ \\
\hline NPV & - Rp2,857,780.8 \\
\hline PBP & $>5$ \\
\hline IRR & $9.3 \%$ \\
\hline
\end{tabular}

Table 18. Calculation Results for Feasibility Study

\begin{tabular}{|l|c|c|c|}
\hline $\begin{array}{c}\text { Feasibility } \\
\text { Analysis }\end{array}$ & $\begin{array}{c}\text { Kaur Re- } \\
\text { gency }\end{array}$ & $\begin{array}{c}\text { Bengkulu } \\
\text { City }\end{array}$ & $\begin{array}{c}\text { Bengkulu } \\
\text { Utara Re- } \\
\text { gency }\end{array}$ \\
\hline NPV & $\begin{array}{c}\text { Rp103,665,46 } \\
3.4\end{array}$ & $\begin{array}{c}\text { Rp102,95 } \\
2,851.3\end{array}$ & $\begin{array}{c}- \\
\text { Rp2,857,780.8 }\end{array}$ \\
\hline PBP & 3.019 Year & $\begin{array}{c}3.014 \\
\text { Year }\end{array}$ & $>5$ Year \\
\hline IRR & $33.8 \%$ & $33.6 \%$ & $9.3 \%$ \\
$(9.95 \%)$ & & Feasible & Not Feasible \\
\hline Decision & Feasible & Fear \\
\hline
\end{tabular}

The last is feasibility analysis of rental locations in North Bengkulu Regency as in the Table 20 and Table 21.

So, this is the summary of parameter in feasibility analysis using NPV, PBP, and IRR of North Bengkulu Regency.

$$
\begin{gathered}
\mathrm{x}(10 \%-9 \%) \\
=9.3 \%
\end{gathered}
$$


$\mathrm{NPV}=\operatorname{Rp}(82,073,882)+\operatorname{Rp}(26,478,754)+$ $R p(9,244,946)+R p 7,523,653+R p 24,312,515+$ Rp83,103,634 $=-\operatorname{Rp} 2,857,781$

$\mathrm{PBP}=>5$

IRR $=9 \%+\frac{R p 1,491,933}{-R p 3,080,472}$

As for the calculation results, for the feasibility anlysis of each selected alternative is shown in Table 18.

\section{CONCLUSION}

Based on calculations carried out in parallel to get a location selection decision from this problem using the P-Median and Feasibility Analysis of the financial aspect (NPV, PBP, and IRR). So it can be concluded that these results provide the best decision to be taken by the company, namely renting a warehouse in Kaur Regency which is the optimal location according to the P-Median calculation and feasible from the financial aspect. Furthermore, the impact that can be felt by the company, such as the initial goal of reducing transportation costs when compared to the existing condition, which was originally the total transportation cost of the Bengkulu area was Rp. 26,996,000 to Rp. 11, 405,305 or decreased by $57.75 \%$. Then because the previous location was not considered in the site selection criteria, the company did not know whether the existing location was optimal. This study also provides an answer that when compared to the location at the current location with the assumption of being able to meet all demands, the proposed location still has an impact on reducing transportation costs and there is a decrease of $30 \%$.

Table 19. Summary of comparison

\begin{tabular}{|l|c|c|c|}
\hline Condition & Existing & Proposal & $\begin{array}{c}\text { de- } \\
\text { crease } \%\end{array}$ \\
\hline Actual & Rp26,996,000 & $\begin{array}{c}\text { Rp11, } \\
405,305\end{array}$ & $57.75 \%$ \\
\hline $\begin{array}{l}\text { Assump- } \\
\text { tion if ex- } \\
\text { isting } \\
\text { point last- } \\
\text { mile can } \\
\text { fullfil all } \\
\text { demand }\end{array}$ & Rp16,476,692 & $R p 11,405,305$ & $30 \%$ \\
\hline
\end{tabular}

\section{REFERENCES}

[1] B. Cahyadi and B. Aulia, "Penentuan Titik Pusat Warehouse dan Sistem Distribusi Portland

Composite Cement di Wilayah Wonogiri," Semin. Nas. Sains dan Teknol. 2018, vol. 1, no. 1, pp. 1-9, 2018.

[2] Keegan, W. J. (2000). Manajemen Pemasaran Global.

[3] D. Çelebi, "Inventory control in a centralized distribution network using genetic algorithms: A

case study," Comput. Ind. Eng., vol. 87, pp. 532-539, 2015, doi:10.1016/j.cie.2015.05.035.

[4] S. A. Kumar and N. Suresh, Production and Operation Management. New Delhi: New Age

International (P) Ltd., Publishers, 2008.

[5] S. M. Daskin, "What You Should Know About Location Modeling," Nav. Reasearch Logist.,

vol. 55 , no. 21 , p. 55 , 2008, doi: $10.1002 /$ nav.

[6] F. Plastria, "Continuous Loaction Problems: Research, Results And Questions," Vrije Univ.

Brussel, vol. 281, pp. 147-167, 1995, doi: 10.1007/9783-030-19111-5_6.

[7] F. K. Yusuf, A. Y. Ridwan, and H. K. Pambudi, "Maritime Inventory Routing Problem:

Application on Discharge the Load of the Ship in Cement Companies to Minimize the

Total Transportation Cost," IOP Conf. Ser. Mater. Sci. Eng., vol. 982, no. 1, 2020, doi:

10.1088/1757-899X/982/1/012056.

[8] I. Fahmi, Pengantar Managemen Keuangan, Edisi Pert. Bandung, 2012.

[9] Jeffery L. Whitten, L. D. Bentley, and K. V. Dittman, Metode Desain \& Analisis Sistem.

Yogyakarta: Andi, 2004.

[10] N. S. Ramadhanti et al., "Feasibility Study of Determination a New Distribution Warehouse

Location Using P-Median and Analytical Network Process Methods in One of the Cement

Industries,” IOP Conf. Ser. Mater. Sci. Eng., 2020.

[11] Kasmir and Jakfar, Studi Kelayakan Bisnis. Jakarta: Predana Media Group, 2015.

[12] Umar, H., 2007. Studi Kelayakan Binis. Jakarta: Gramedia Pusaka Utama. 